Edubiotik : Jurnal Pendidikan, Biologi dan Terapan
ISSN 2528-679X (print), ISSN 2597-9833 (online)
Volume 5, Nomor 01, Tahun 2020, Hal. 55-61
Available online at:
http:/lejurnal.budiutomomalang.ac.id/index.php/edubiotik

Research Article

open Access

\title{
Keberagaman jenis jamur makroskopis di kawasan wisata sumber ubalan kediri
}

\author{
Farida Nurlaila Zunaidah ${ }^{1}$, Tutut Indah Sulistiyowati² \\ ${ }_{1}^{1}$ Program Studi Pendidikan Sekolah Dasar, Universitas Nusantara PGRI Kediri, Kediri, Indonesia \\ 2Program Studi Pendidikan Biologi, Universitas Nusantara PGRI Kediri, Kediri, Indonesia \\ Email: farida@unpkediri.ac.id*, tututindah.team@gmail.com
}

\begin{tabular}{|c|c|}
\hline Informasi Artikel & ABSTRACT \\
\hline $\begin{array}{l}\text { Submit: } 15-01-2019 \\
\text { Diterima: } 25-02-2020 \\
\text { Dipublikasikan: } 27-02-2020\end{array}$ & $\begin{array}{l}\text { The data collection of mushroom species found in Ubalan source tourism areas needs to } \\
\text { be done as a source of data on the diversity of mushroom species as decomposers of } \\
\text { organic material. This type of research is a descriptive exploratory study with methods. } \\
\text { roaming modified with VES (Visual Encounter Survey). The research instrument used was } \\
\text { a logbook, observation sheet, and the key book of determination. All mushrooms were } \\
\text { collected in a collection bottle and identified by using a macro mushroom determination } \\
\text { key in the Botany Laboratory of the Nusantara University PGRI Kediri. The data of this } \\
\text { research are the types of macroscopic fungi found during observation. The data analysis } \\
\text { technique used is descriptive qualitative. The results showed that there were twelve } \\
\text { identified fungal families, namely Auriculariae, Tricholomataceae, Ganodermataceae, } \\
\text { Amanitaceae, Hymenogastraceae, Marasmiaceae, Russulaceae, Agaricaceae, } \\
\text { Amanithaceae, Mycenaceae, Polyporaceae and Parmeliaceae. The conclusions of this } \\
\text { study indicate that the area of the tourist area of the Ubalan has a variety of macroscopic } \\
\text { fungi. } \\
\text { Key words: Diversity, Mushrooms, Ubalan }\end{array}$ \\
\hline Penerbit & ABSTRAK \\
\hline $\begin{array}{l}\text { Program Studi Pendidikan Biologi, } \\
\text { IKIP Budi Utomo, Malang, Indones }\end{array}$ & $\begin{array}{l}\text { Pendataan jenis jamur yang terdapat di kawasan wisata sumber Ubalan perlu dilakukan } \\
\text { sebagai sumber data keberagaman jenis jamur sebagai pengurai materi organik. Tujuan } \\
\text { penelitian ini, yaitu untuk mengetahui jenis jamur makroskopis di kawasan wisata sumber } \\
\text { Ubalan. Jenis penelitian merupakan penelitian deskriptif eksploratif dengan metode jelajah } \\
\text { yang dimodifikasi dengan VES (Visual Encounter Survey). Instrumen penelitian yang } \\
\text { digunakan adalah log book, lembar pengamatan, dan buku kunci determinasi. Semua } \\
\text { jamur dikoleksi dalam botol koleksi dan diidentifikasi dengan menggunakan kunci } \\
\text { determinasi jamur makro di Laboratorium Botani Universitas Nusantara PGRI Kediri. Data } \\
\text { penelitian ini berupa jenis-jenis jamur makroskopis yang ditemukan selama pengamatan. }\end{array}$ \\
\hline 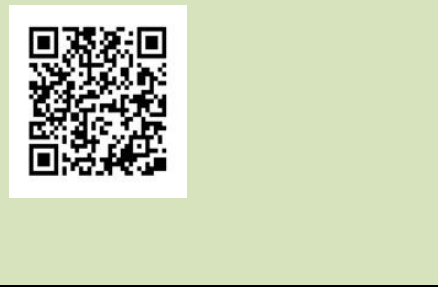 & $\begin{array}{l}\text { Teknik analisis data yang digunakan adalah deskriptif kualitatif. Hasil penelitian } \\
\text { menunjukkan bahwa terdapat dua belas famili jamur yang telah teridentifikasi, yaitu } \\
\text { Auriculariae, Tricholomataceae, Ganodermataceae, Amanitaceae, Hymenogastraceae, } \\
\text { Marasmiaceae, Russulaceae, Agaricaceae, Amanithaceae, Mycenaceae, Polyporaceae } \\
\text { dan Parmeliacea. Simpulan penelitian ini menunjukkan bahwa kawasan wisata sumber } \\
\text { ubalan memiliki jenis jamur makroskopis yang beragam. } \\
\text { Kata kunci: Jamur, Keberagaman, Ubalan }\end{array}$ \\
\hline
\end{tabular}

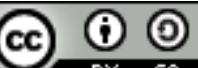

This Edubiotik : Jurnal Pendidikan, Biologi dan Terapan is licensed under a CC BY-SA (Creative Commons Attribution-ShareAlike 4.0 International License) 


\section{PENDAHULUAN}

Ubalan merupakan kawasan hutan lindung yang dibuka sebagai kawasan wisata. Kawasan ini memiliki luas wilayah sebesar sepuluh hektar, yang terbagi menjadi tiga kawasan. Kawasan pertama yaitu berupa area parkir, registrasi dan area bermain, kawasan kedua berupa perairan (sumber air dan sungai), dan kawasan ketiga berupa hutan lindung itu sendiri (Pemerintah Kabupaten Kediri, 2015). Kawasan ini terletak pada $7^{\circ} 52^{\prime} 57,7^{\prime \prime} \mathrm{LS}-112^{\circ} 8^{\prime} 59,0^{\prime \prime} \mathrm{BT}$ dengan ketinggian $400 \mathrm{mdpl}$. Pada kawasan hutan lindung biasanya digunakan untuk meneliti berbagai macam keanekaragaman tumbuhan.

Topografi alam yang terdiri atas perairan dan daratan yang berdekatan memungkinkan adanya beraneka ragam makhluk hidup yang menghuni. Tumbuhan yang mendominasi kawasan ini adalah habitus pohon (Mualfianah, 2018). Pohon merupakan organisme penyumbang serasah terbesar (Susanti \& Halwany, 2016). Wilayah yang memiliki keragaman pohon tinggi akan memiliki banyak serasah (Syahbuddin \& Maulinda, 2010). Serasah merupakan sumber mineral alami bagi jasad renik yang kemudian mengalami dekomposisi dan mineralisasi (Aprianis, 2011). Salah satu organisme yang bertanggung jawab terhadap proses dekomposisi adalah jamur, baik jamur mikroskopis maupun makroskopis. Penyebaran habitat jamur dihutan biasanya terdapat pada tanah, serasah daun, dan kayu yang sudah lapuk/mati (Alsohaili \& Bani-Hasan, 2018). Pembusukan pada serasah daun dan pelapukan kayu akan menyediakan nutrisi yang besar bagi kelangsungan hidup jamur. Sehingga hutan merupakan habitat yang baik bagi jamur karena menyediakan faktor biotik dan abiotik bagi jamur (Priskila, Ekamawanti, \& Herawatiningsih, 2018).

Jamur merupakan organisme yang memperkaya keanekaragaman jenis makhluk hidup pada dunia tumbuhan (Branco, 2019). Jamur memiliki kekhasan, dimana jamur merupakan organisme yang tidak berklorofil sehingga menggantungkan hidupnya pada makhluk hidup lain baik yang masih hidup maupun yang sudah mati (Bakhshaliyeva, Cabrayılzadə, İslamova, Namazov, \& Hasanova, 2019). Hal inilah yang mempengaruhi penyebaran keanekaragaman jamur baik didarat maupun di air (Branco, 2019). Diantara keberagaman jenis jamur yang mendominasi daratan, jenis jamur makroskopis banyak ditemukan hampir disebagian besar daratan. Jamur makroskopis merupakan semua jamur yang berukuran makro, bersel banyak, dan dapat diamati dengan mata telanjang. Sebagian besar jamur makroskopis hidup di terrestrial (Mayasari, Christita, \& Suryawan, 2018; Priyamvada et al., 2017). Kebanyakan jamur hidup pada habitat lembab. Jamur dapat menggunakan tanah, kayu, daun, dan bahkan bebatuan sebagai substrat tumbuhnya (Rudolph, Maciá-Vicente, Lotz-Winter, Schleuning, \& Piepenbring, 2018). Seperti penelitian sebelumnya yang dilakukan oleh Purwanto et al., 2017 dan Nasution, Rahayu Prasetyaningsih, \& Ikhwan, 2018 yang menyatakan bahwa keanekaragaman jenis jamur makroskopis yang terdapat dihutan ditentukan oleh kondisi habitat tempat tumbuh jamur. Jamur membutuhkan tempat tumbuh yang relatif lembab dan intensitas cahaya yang relatif sedikit untuk mempertahankan hidupnya (Anggraini, Khotimah, \& Turnip, 2015). Berdasarkan studi pendahuluan, diketahui bahwa kawasan Ubalan memiliki potensi sebagai habitat jamur. Namun belum pernah dilakukan penelitian untuk mendata keragaman jamur yang terdapat di kawasan wisata sumber Ubalan. Tujuan penelitian ini adalah untuk mengidentifikasi jenis jamur makroskopis yang ada di kawasan wisata sumber ubalan. 


\section{METODE}

Penelitian ini merupakan penelitian deskriptif eksploratif yang dilaksanakan selama bulan Desember 2018 di hutan pada kawasan wisata Ubalan dengan suhu udara rata-rata yang tercatat selama pengambilan data adalah $27 \pm 1^{\circ} \mathrm{C}$ dengan kelembaban $80 \pm 1,5 \%$. Tahap-tahap dalam penelitian meliputi tahap persiapan, pengolahan data, dan penentuan hasil. Pada tahap persiapan meliputi persiapan alat dan bahan yang akan digunakan dalam survey. Alat yang digunakan diantaranya, soil tester, Ph meter, kamera digital, dan thermohigrometer. Bahan yang digunakan meliputi, plastik, botol koleksi, sarung tangan, sekop, kertas label, dan log book.

Pengambilan sampel jamur dengan menggunakan metode jelajah yang dipadukan dengan VES (Visual Encounter Survey). Populasi penelitian ini adalah keseluruhan jamur makroskopis yang terlihat pada plot penjelajahan. Pengambilan sampel dibagi atas beberapa plot pada tempat yang berbeda. Hal ini bertujuan untuk mencari keberagaman jamur pada tempat yang berbeda. Semua sampel jamur yang ditemukan diidentifikasi di laboratorium Botani Universitas Nusantara PGRI Kediri dengan menggunakan beberapa kunci determinasi (Lodge, Ammirati, \& Dell, 2004) dan (Darwis, Mantovani, \& Supriati, 2011). Instrumen penelitian berupa lembar observasi, log book dan buku kunci determinasi. Tahap pengolahan data adalah mengidentifikasi jenis-jenis jamur makroskopis yang telah ditemukan dari beberapa plot. Jamur-jamur yang telah teridentifikasi jenisnya akan ditulis pada log book dan digunakan sebagai data hasil penelitian. Tahap penentuan meliputi menentukan hasil yang telah teridentifikasi. Jamur yang telah teridentifikasi dikelompokkan berdasarkan filumnya, selanjutnya data tersebut ditabulasi sebagai data penelitian. Teknik analisis data penelitian dilakukan dengan melakukan pendataan pada semua jenis jamur berdasarkan filum, family, dan lokasi ditemukannya jamur makroskopis.

\section{HASIL DAN PEMBAHASAN}

Berdasarkan data hasil pengamatan dibeberapa plot yang sudah ditentukan, terdapat sebelas famili dengan 17 jenis jamur yang berbeda (Tabel 1). Jamur dari famili Tricholomataceae merupakan jamur yang paling banyak dijumpai.

Tabel 1. Daftar Jenis-Jenis Jamur Pada Kawasan Wisata Sumber Ubalan

\begin{tabular}{clc}
\hline Filum & \multicolumn{1}{c}{ Famili } & Lokasi \\
\hline Basidiomycota & Auriculariaceae & Plot 1 dan 3 \\
& Tricholotaceae & Plot 1 dan 2 \\
Ganodermataceae & Plot 1 dan 3 \\
Hymenogastraceae & Plot 2 \\
Marasmiaceae & Plot 3 \\
Russulaceae & Plot 3 \\
Agaricaceae & Plot 3 \\
Amanithaceae & Plot 3 \\
& Mycenaceae & Plot 3 \\
& Polyporaceae & Plot 3 \\
\hline
\end{tabular}

Berdasarkan tabel diatas, famili yang banyak dijumpai adalah Auriculariaceae, Tricholotaceae dan Ganodermataceae. Famili tersebut tersebar hampir diseluruh plot. Terutama famili Ganodermataceae, karena sering dijumpai di batang-batang pohon yang masih hidup maupun batang pohon yang sudah lapuk. Famili Ganodermaceae mirip dengan jamur sterum. Hal ini sejalan dengan hasil penelitian 
(Wahyudi, Linda, \& Khotimah, 2012) yang menunjukkan bahwa jamur tersebut sering ditemukan pada batang pohon yang telah lapuk/mati dan dapat digolongkan sebagai jamur saprofit. Hal tersebut diperkuat dengan adanya penelitian yang dilakukan oleh (Anggraini et al., 2015) menyatakan bahwa ordo Aphylloporales yang termasuk dalam famili Ganoderma memiliki kemampuan adaptasi yang baik dibandingkan kelompok ordo yang lainnya. Kelompok pada ordo tersebut dapat beradaptasi pada kondisi lingkungan yang kurang mendukung pertumbuhannya. Ordo ini mampu beradaptasi pada suhu $30^{\circ} \mathrm{C}$ dan pada kelembapan $70 \%$ yang merupakan suhu dan kelembapan rata-rata pada kawasan wisata sumber ubalan.

Jenis jamur lain yang berasal dari famili Tricholotaceae dan Agaricaceae hidupnya dipengaruhi oleh beberapa faktor yakni musim dan keberadaan dari spora jamur (Proborini, 2006). Lebih lanjut hasil penelitian (Proborini, 2006) menyatakan bahwa spora-spora jamur dorman pada musim kemarau akan segera germinasi dan tumbuh membentuk badan buah. Jenis-jenis jamur yang lain seperti Amanithaceae, Russulaceae dan Mycenaceae habitatnya tersebar merata pada tanah dan serasah daun. Beberapa jamur yang hidup pada tanah dan serasah daun mungkin lebih sedikit ditemui.

Berbagai jenis jamur yang telah ditemukan ada yang tergolong dalam jamur beracun dan jamur tidak beracun. Fitriani, Krisnawati, Anorda, \& Lanjarini, (2018) menyatakan jamur yang dapat dikonsumsi mempunyai kandungan garam mineral yang tinggi daripada yang terkandung didalam daging sapi atau daging domba. Selain mengandung garam mineral juga mengandung protein yang tinggi, garam-garam besi, kalium, tembaga, kapur, vitamin B, dan vitamin $\mathrm{D}$. Pada jamur beracun, biasanya memiliki ciri warna yang sangat mencolok serta bau yang menyengat. Jamur beracun tidak dapat dikonsumsi karena mengandung senyawa beracun yang salah satunya bernama sulfida.

Pertumbuhan pada jamur dipengaruhi oleh beberapa faktor yakni suhu, Ph dan kelembapan seperti yang tercantum dalam Tabel 2 berikut.

Tabel 2. Faktor-Faktor Yang Mempengaruhi Pertumbuhan Jamur

\begin{tabular}{ccc}
\hline No & Faktor yang Mempengaruhi & Hasil pengukuran \\
\hline 1 & Suhu & $27-32{ }^{\circ} \mathrm{C}$ \\
2 & $\mathrm{Ph}$ & $6-7$ \\
3 & Kelembaban & $82-88 \%$ \\
\hline
\end{tabular}

Jumlah pertumbuhan jamur akan dipengaruhi oleh faktor lingkungan yang akan mendukung pertumbuhan jamur. Jamur makroskopis dapat hidup secara berkoloni maupun individu. Faktor suhu, Ph, dan kelembaban sangat mempengaruhi keberlangsungan hidup jamur (Wati, Noverita, \& Setia, 2019). Lebih lanjut lagi berdasarkan penelitian (Tajul \& Arico, 2019) rata-rata jamur makroskopis dapat hidup pada $\mathrm{Ph}$ yang normal dan suhu yang tidak terlalu tinggi. Namun kondisi pada tiap-tiap plot dapat bervariasi, sehingga mempengaruhi keberagaman jamur yang tumbuh pada plot tersebut. Jamur makroskopis bersifat kosmopolitan dimana dalam pertumbuhannya banyak faktor yang mempengaruhi penyebarannya di alam, oleh sebab itu setiap jamur memiliki daya adaptasi yang berbeda-beda. Sehingga secara umum jamur makroskopis dapat tumbuh dengan baik pada kisaran suhu $20-30{ }^{\circ} \mathrm{C}$ dengan kelembapan ideal $80-90 \%$ (Ulya, Leksono, \& Khastini, 2017). Terlepas dari faktor-faktor tersebut, pertumbuhan jamur makroskopis juga tergantung dari jenis-jenis jamur makroskopis itu sendiri (Marzuki, Rossiana, \& Normanita, 2017). 


\section{SIMPULAN}

Berdasarkan hasil penelitian dapat disimpulkan bahwa pada kawasan wisata sumber ubalan ditemukan beberapa jenis jamur makroskopis dari berbagai famili, yaitu Auriculariaceae, Tricholotaceae, Ganodermataceae, Hymenogastraceae, Marasmiaceae, Russulaceae, Agaricaceae, Amanithaceae, Mycenaceae, Polyporaceae, Parmeliaceae. Dari beberapa famili yang ditemukan yang banyak ditemui dari beberapa plot berasal dari famili Auriculariaceae, Tricholotaceae, Ganodermataceae dan Agaricaceae. Aspek morfologi dan manfaat jamur perlu diteli untuk mengetahui kelompok jamur beracun dan tidak beracun.

\section{UCAPAN TERIMA KASIH}

Terima kasih kepada semua pihak yang sudah membantu dan berkontribusi dalam penelitian kami ini. Rekan penelitian yang sudah banyak membantu berjalannya penelitian. Mahasiswa mahasiswa pencinta alam yang membantu dalam jelajah hutan dan sebagai petunjuk arah. Mahasiswa tingkat II Prodi Biologi yang telah membantu dalam mengidentifikasi dan mengolah data. Serta pihak-pihak lain yang tidak bisa kami sebutkan satu persatu telah banyak berkontribusi dalam penelitian ini.

\section{RUJUKAN}

Alsohaili, S. A., \& Bani-Hasan, B. M. (2018). Morphological and Molecular Identification of Fungi Isolated from Different Environmental Sources In The Northern Eastern Desert Of Jordan. Jordan Journal of Biological Sciences, 11(3), 329-337. Retrieved from https://www.researchgate.net/publication/3233 77785

Anggraini, K., Khotimah, S., \& Turnip, M. (2015). Jenis-Jenis Jamur Makroskopis Di Hutan Hujan Mas Desa Kawat Kecamatan Tayan Hilir Kabupaten Sanggau. Protobiont, 4, 60-64. Retrieved from http://jurnal. untan.ac.id/index.php/jprb/article/view/13305/11996

Aprianis, Y. (2011). Produksi Dan Laju Dekomposisi Serasah Acacia Crassicarpa A. Cunn In PT. Arara Abadi. Tekno Hutan Tanaman, 4(1), 41-47. Retrieved from https://docplayer.info/261254-Produksi dan-laju-dekomposisi-serasah-litterfall-production-and-decomposition-rate-of.html

Bakhshaliyeva, K. F., Cabrayılzadə, S. M., İslamova, Z. B., Namazov, N. R., \& Hasanova, A. R. (2019). The General Characteristic of Anamorphic Fungi Spread In Azerbaijan. International Journal of Recent Technology and Engineering, 8(3), 2208-2210. https://doi.org/10.35940/ijte.C4591.098319

Branco, S. (2019). Fungal Diversity from Communities to Genes. Fungal Biology Reviews. https://doi.org/10 .1016/j.fbr.2019.06.003

Darwis, W., Mantovani, Andria rosa, \& Supriati, R. (2011). Determinasi Jamur Lycoperdales Yang Terdapat Di Desa Pajar Bulan Kecamatan Semidang Alas Kabupaten Seluma Bengkulu. Konservasi Hayati, 07(01), 6-12. Retrieved from http://repository.unib.ac.id/7862/1/Jurnal Welly-Rochmah- MartovaniApril 2011.pdf

Fitriani, L., Krisnawati, Y., Anorda, M. O. R., \& Lanjarini, K. (2018). Jenis-Jenis Dan Potensi Jamur Makroskopis Yang Terdapat Di Pt Perkebunan Hasil Musi Lestari Dan Pt Djuanda Sawit Kabupaten Musi Rawas. Jurnal Biosilampari: Jurnal Biologi, 1(1), 21-28. https://doi.org/10.31540/biosilampari.v1 i1.49

Lodge, D. J., Ammirati, J. F., \& Dell, T. E. O. (2004). Collecting And Describing Macrofungi. Elsevier Academic Press. Retrieved from https://www.fpl.fs.fed.us/documnts/pdf2004/fpl_2004_lodge001.pdf 
Marzuki, B. Ma., Rossiana, N., \& Normanita. (2017). Diversity Of Macrofungi On Wood In Forest Nature Reserve Of Bojonglarang Jayanti Cianjur West Java. Journal of Bacteriology \& Mycology, 4(1), 2528. https://doi.org/10.15406/jbmoa.2017.04.00080

Mayasari, A., Christita, M., \& Suryawan, A. (2018). The Diversity of Macroscopic Fungi Species of The Wallacea in The Arboretum of BP2LHK Manado. Jurnal Wasian, 5(2), 105-114. https://doi.org/10.2 0886/jwas.v5i2.4380

Mualfianah, S. (2018). Analisis Vegetasi Dan Estimasi Stok Karbon Di Kawasan Wisata Sumber Ubalan Dusun Kalsan Kecamatan Plosoklaten Kabupaten Kediri. Simki-Techsain, 02(03), 0-8. Retrieved fromhttp://simki.unpkediri.ac.id/mahasiswa/file_artikel/2018/fc1ebd90fb91f1941cb78eba339c3411.pdf

Nasution, F., Rahayu Prasetyaningsih, S., \& Ikhwan, M. (2018). Identifikasi Jenis Dan Habitat Jamur Makroskopis Di Hutan Larangan Adat Rumbio Kabupaten Kampar Provinsi Riau. Wahana Forestra: Jurnal Kehutanan, 13(1), 64-76. https://doi.org/10.31849/forestra.v13i1.1556

Pemerintah Kabupaten Kediri. (2015). Sumber Ubalan. 17 September. Retrieved January 7, 2020,Retrieved from https://kedirikab.go.id/index.php?option=com_content\&view=article\&id=686\&lte $\mathrm{mid}=800$

Priskila, Ekamawanti, H. A., \& Herawatiningsih, R. (2018). Keanekaragaman Jenis Jamur Makroskopis Di Kawasan Hutan Sekunder Areal luphhk-Hti Pt. Bhatara Alam Lestari Kabupaten Mempawah. Jurnal Hutan Lestari, 6(3), 569-582. Retrieved from http://jurnal.untan.ac.id/index.php/jmfkh/article/view/269 $53 / 75676577585$

Priyamvada, H., Akila, M., Singh, R. K., Ravikrishna, R., Verma, R. S., Philip, L., Gunthe, S. S. (2017). Terrestrial Macrofungal Diversity From The Tropical Dry Evergreen Biome Of Southern India And Its Potential Role In Aerobiology. PLoS ONE, 12(1), 1-21. https://doi.org/10.1371/journal.pone.0169333

Proborini, Meitini w. (2006). Eksplorasi Dan Identifikasi Jenis - Jenis Jamur Klas Basidiomycetes Di Kawasan Bukit Jimbaran Bali. Jurnal Biologi, 16(2), 45-47. https://doi.org/10.24843/jbiounud

Purwanto, P. B., Zaman, M. N., Yusuf, M., Romli, M., Syafi, I., Hardhaka, T.,Yugo, M. H. (2017). Inventarisasi Jamur Makroskopis di Cagar Alam Nusakambangan Timur Kabupaten Cilacap Jawa Tengah. Proceeding Biology Education Conference, 14(1), 79-82. Retrieved from https://jurnal.uns. ac.id/prosbi/article/view/18700/14808

Rudolph, S., Maciá-Vicente, J. G., Lotz-Winter, H., Schleuning, M., \& Piepenbring, M. (2018). Temporal Variation of Fungal Diversity In A Mosaic Landscape In Germany. Studies in Mycology, 89, 95-104. https://doi.org/10.1016/j.simyco.2018.01.001

Susanti, pranatasari dyah, \& Halwany, W. (2016). Dekomposisi Serasah Dan Keanekaragaman Makrofauna Tanah Pada Hutan Tanaman Industri Nyawai (Ficus variegate. Blume) Litter. Jurnal IImu Kehutanan, 11(2), 212-223. https://doi.org/10.22146/jik.28285

Syahbuddin, C., \& Maulinda, D. (2010). Laju Dekomposisi Serasah Daun Beberapa Jenis Pohon Pionir Di Plot Permanen Hutan Penelitian Dan Pendidikan Biologi (HPPB) Universitas Andalas Padang. Prosiding Seminar Dan Rapat Tahun BKS- PTN Wilayah Barat Ke 2. Retrieved from https://id.123dok.com/document/download/yd7k25jy

Tajul, R., \& Arico, Z. (2019). Types of Macroscopic Fungus in Bukit Lawang TNGL Sumatera Utara, 1(2), 43-47. Retrieved from https://ejurnalunsam.id/index.php/jbs/article/view/1673/1248

Ulya, ahmad ni'matullah Al, Leksono, suroso mukti, \& Khastini, rida oktorida. (2017). Biodiversitas Dan Potensi Jamur Basidomycota Di Kawasan Kasepuhan Cisungsang, Kabupaten Lebak, Banten. AlKauniyah: Jurnal Biologi, 10(1), 9-16. https://doi.org/10.15408/kauniyah.v10i1.4513

Wahyudi, A. eko, Linda, R., \& Khotimah', S. (2012). Inventarisasi Jamur Makroskopis Di Hutan Rawa Gambut Desa Teluk Bakung Kecamatan Sungai Ambawang Kabupaten Kubu Raya. Protobiont, 1(1), 8-11. https://doi.org/10.1016/j.abb.2007.11.016 
Wati, R., Noverita, \& Setia, tatang mitra. (2019). Keanekaragaman Jamur Makroskopis Dibeberapa Habitat Kawasan Taman Nasional Baluran. Jurnal Biologi Al-Kauniyah, 12(2), 171-180. https://doi.org/10. 15408/kauniyah.v12i2.10363 